\title{
The consumption of the white-lipped frog (Leptodactylus macrosternum Leptodactylidae: Anura) in the state of Rondônia in the Brazilian Amazon
}

\author{
Marcela Alvares Oliveira ${ }^{1 \%}$ \\ Ana Paula Vitoria Costa Rodrigues ${ }^{2}$ \\ Mariluce Rezende Messias 1 \\ Carolina Rodrigues da Costa Doria ${ }^{1}$ \\ ${ }^{1}$ Universidade Federal de Rondônia, Campus Universitário José Ribeiro Filho \\ CEP 76.801-059, Porto Velho - RO, Brasil \\ ${ }^{2}$ Escola de Ensino Superior da Amazônia, CEP 66.053-180, Belém - PA, Brasil \\ * Autor para correspondência \\ marcela.mugrabe@gmail.com
}

Submetido em 21/03/2021

Aceito para publicação em 11/08/2021

\section{Resumo}

O consumo da rã-manteiga (Leptodactylus macrosternum Leptodactylidae: Anura) no estado de Rondônia na Amazônia brasileira. O registro do uso de anuros para autoconsumo alimentar na Amazônia brasileira é inexistente. Diante desse cenário, o objetivo desse estudo é apresentar o primeiro registro de uso alimentar de rã-manteiga na Amazônia rondoniense. Os dados foram levantados via entrevista com dois migrantes do estado do Espirito Santo, atualmente residentes no município de Itapuã do Oeste em Rondônia. Os entrevistados faziam o uso de uma rã-manteiga (possivelmente Leptodacylus latrans) em seu estado de origem, e após localizarem uma espécie similar (Leptodactylus macrosternum) e confirmarem a possibilidade de consumo com a mãe via WhatsApp, passaram a consumir a rã. Esse registro demonstra como certos costumes relacionados com o consumo de animais silvestres pode ser mantido em novas localidades e como as ferramentas de mensagens instantâneas podem colaborar com troca de informações sobre espécies de caça.

Palavras-chave: Anfíbios; Caça; Entrevista; Etnozoologia; WhatsApp

\section{Abstract}

The consumption of anurans by subsistence hunters in the Brazilian Amazon is unrecorded. Given this scenario, the objective of this study is to present the first record of white-lipped frog consumption by subsistence hunters in the Amazon region of Rondônia. The data were collected through interviews with two migrant hunters from the state of Espírito Santo, currently residing in the municipality of Itapuã do Oeste in Rondônia. The hunters used to consume white-lipped frog (possibly Leptodactylus latrans) in their state of origin, and after locating a similar species (Leptodactylus macrosternum) and confirming the possibility of consumption with the mother through WhatsApp, they started consuming the frog. This record demonstrates how certain habits related to the consumption of wild animals can be maintained in new locations and how instant messaging tools can collaborate with information exchange about game species.

Key words: Amphibians; Ethnozoology; Interview; Hunting; WhatsApp 
The consumption of wild animals involves a wide spectrum of species, including, to a lesser extent, anurans (FERNANDES-FERREIRA et al., 2013; MENDONÇA et al., 2014). In the Brazilian Amazon the records of alimentary consumption of anurans are inexistent (FERREIRA et al., 2012; LEMOS et al., 2018; BELFORT et al., 2020; RAMOS et al., 2020), being concentrated in mammals (STAFFORD et. al, 2017), while in other parts of the world the consumption of anurans is common (e.g., ONADEKO et al., 2011).

Given the above, the objective of this work is to describe the use of the white-lipped frog Leptodacylus macrosternum as a food resource in Amazonia and the use of instant messaging apps to exchange information about game animals.

The municipality of Itapuã do Oeste belongs to the state of Rondônia, located in the southwestern part of the Amazon biome, with a population of 8,566 inhabitants, and rural population consisting of 3,344 inhabitants (IBGE, 2017). About $45.7 \%$ of the resident population of the state of Rondônia are immigrants (IBGE, 2007), a profile also observed in the municipality.

The interview was conducted with two rural residents from Itapuã do Oeste in the state of Rondônia during the period of March 2019. The interviewees lawfully agreed to participate in the present survey by reading and signing the Consent Form, where they have clarified their right to remain anonymous and to leave at any time during the interview. The residents identified themselves as hunters, but only provided information about the consumption of the white-lipped frog and associated ethnozoological aspects. This work was submitted and approved to the Research Ethics Committee, which identification number was 2661332 .

The two interviewees are cousins, both males, aged 35 and 38 years old, born in the rural area of Vitória (Espírito Santo) in the Atlantic Forest biome. When residing in Vitória, both of them worked with small cattle and coffee plantation on a family farm that had been in the family since their grandparents' generation. Both the cousins carried out the hunting activity in their place of origin and consumed a frog species of the region (Leptodacylus), a habit passed down from generations that, over time, learned how to locate, identify, capture and also learned about the species reproductive cycle. They moved to Rondônia in 2015 to work on a farm in the rural area of Itapuã do Oeste (Figure 1).

FIGURE 1: Map showing the interviewees' location of origin (in red) and current residence (in yellow).

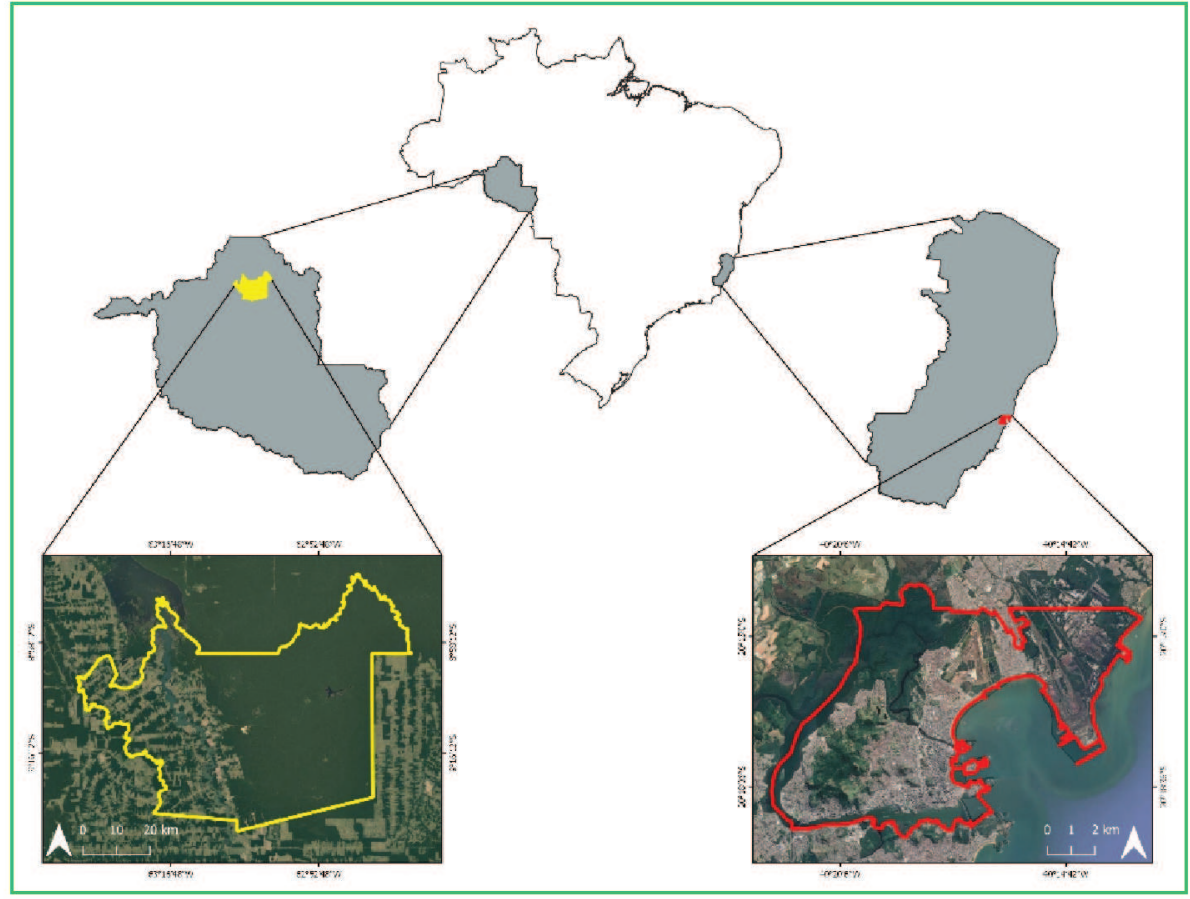


Both interviewees reported that when they entered the state of Rondônia they continued their hunting activity, which did not include white-lipped frogs as a target species. One year after arriving in the state, they found a mud puddle in the pasture with several individuals of Leptodactylus macrosternum (Figure 2). This species can be found in the most diverse environments with different levels of preservation in the state of Rondônia (CALDERON et al., 2009), facilitating its location and capture. Unsure if they were the same white-lipped frogs consumed in Espírito Santo, they took a picture and sent it via Whatsapp to the oldest hunter's mother so she could confirm the species. Based on visible traits, the description of the capture site and the season of the year, the mother confirmed that the frog could be eaten without any problems or aggravation. After the confirmation, they started consuming the frog, only at the height of the flood period in the region (corresponding to months from October to April). The only cooking preparation used by the interviewees was frying, which was recommended by the mother to avoid any kind of contamination. According to the 38-year-old interviewee, it was necessary for the animal to be well fried since the hot fat kills all possible pathogens.
The interviewees were asked if this consumption habit was shared with the other eleven workers in the locality. They affirmed that they were the only ones in the region who did this type of hunting and that everybody else observed it with strangeness, due to the fact that white-lipped frogs are not edible animals in the state of Rondônia, and are considered repulsive, which is related to the presence of poison in these animals. This opinion has been recorded in different studies about the population's perception of anurans (e.g., DIAS et al., 2018; FERREIRA; FERREIRA, 2019). According to the interviewees, the frogs in the dry season and at the beginning of the rainy season have a small body size, not having a positive cost-benefit ratio for capture. This observation highlights the relationship of the hunters' knowledge to the aspects related to the reproduction of the species (OLIVEIRA; FREIRE, 2015, confirming the observations of Camurugi et al. (2017). Another aspect highlighted by the interviewees regarding the size, is that the frogs have not yet reproduced, and their removal would be negative for the population, thus emphasizing that hunters adopt fauna management measures based on their observations (OLIVEIRA; CALOURO, 2019).

FIGURE 2: Individual from Leptodactylus macrosternum. Font: Alves-Silva. K. R.

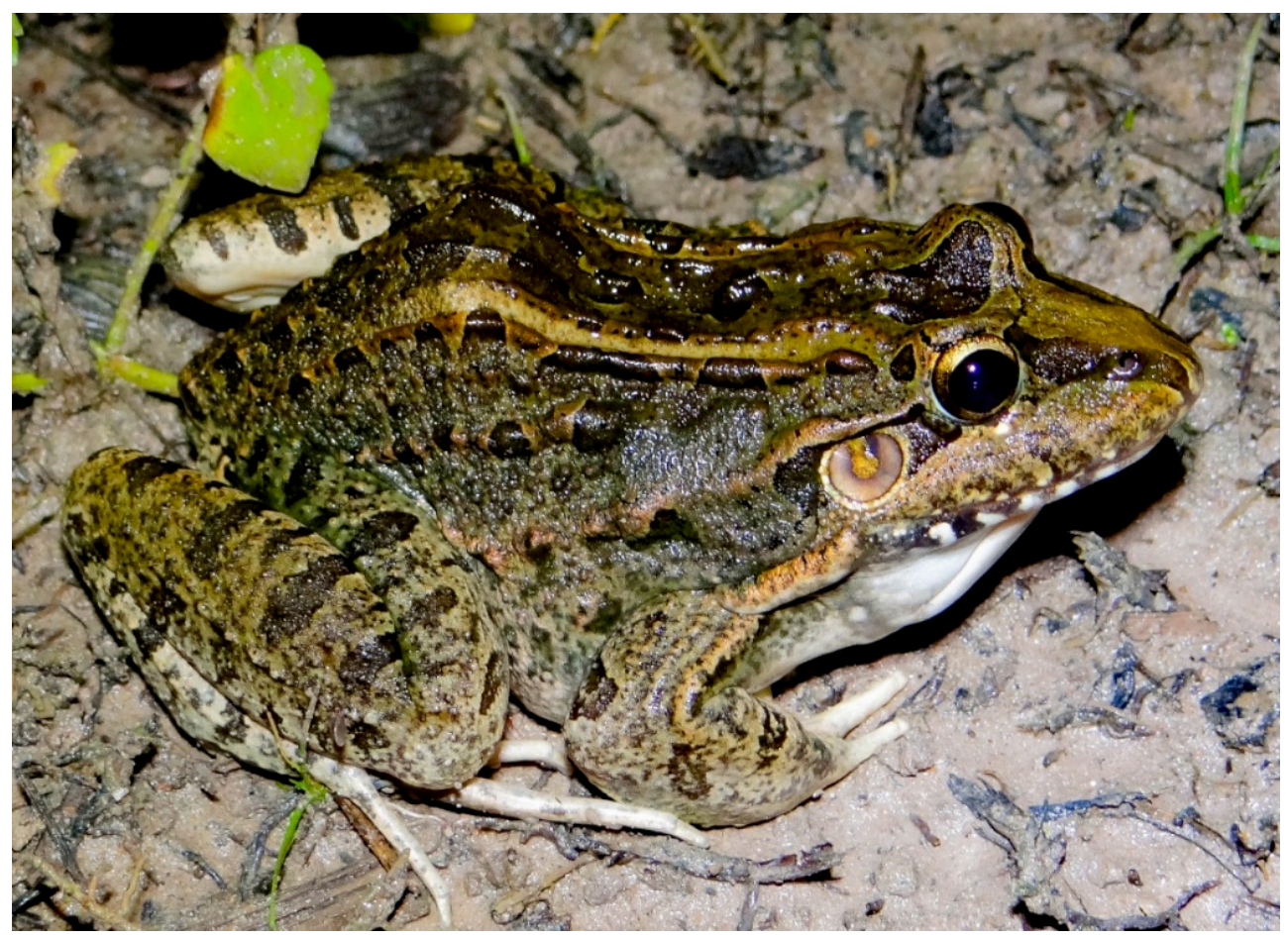


The consumption of the white-lipped frog Leptodactylus latrans is recorded in the state of Espírito Santo (FERREIRA; FERREIRA, 2019), and this is possibly the species previously consumed by the interviewees. Although there are no records of frog consumption in the Amazon region, this practice is observed in the Caatinga, not only as food, but also in traditional medicine (FERNANDES-FERREIRA et al., 2013; ALVES et al., 2017; CAMPOS et al., in press).

Social instant messaging networks have gained prominence in conducting research (VAN VLIET et al., 2017; MCCUBBIN, 2020) and exchanging information on occurrence and recording of biodiversity (SUPRAYITNO et al., 2017), but their participation in the exchange of traditional ecological knowledge associated with hunting and about the possibility of animal consumption is not yet investigated.

We emphasize that the present paper presents the first record of white-lipped frog consumption in the state of Rondônia. This record demonstrates that certain habits of wild animal consumption can be maintained even when new species are available due to preference, and that electronic messaging apps favor the exchange of information about new hunting habits. We suggest that future studies to investigate: 1 ) the species added to their hunting spectrum and which were already hunted in their place of origin among immigrant hunters and 2) the role of instant messaging apps in exchange of traditional ecological knowledge associated with hunting.

\section{Acknowledgments}

We would like to thank the interviewees for providing the information, Paulo Twardowski and his family and Julia Batista for logistical support, as well as the anonymous reviewers for their contributions in improving the manuscript.

\section{References}

ALVES, R. R. N.; OLIVEIRA, T. P. R.; MEDEIROS, M. F. T. Trends in medicinal uses of edible wild vertebrates in Brazil. Evidence-based Complementary and Alternative Medicine, New York, v. 2017, p. 4901329, 2017.
BELFORT, M. J. S.; BARBOSA, G. S.; SILVA, C. P.; OLIVEIRA, M. A. Perception of subsistence hunters in Lower Madeira on the impact of the Santo Antônio Hydroelectric Power Plant. Revista Brasileira de Ciências da Amazônia, Rolim de Moura, v. 9, n. 3, p. 16-25, 2020.

CALDERON, L. A.; DELAIX-ZAQUEO, K.; ZAQUEO, K. D.; SERRANO, R. P.; MESSIAS, M. R.; CARDOZO-FILHO, J. L.; DINIZ-SOUSA, R.; HOLANDA, R. J.; REGO, T. B.; STABELI, R. G. Amphibia, Anura, Leptodactylidae, Leptodactylus chaquensis: Distribution extension and geographic distribution map. Check List, Rio Claro, v. 5, n. 3, p. 425-427, 2009.

CAMPOS, F. L.; NETO, E. M. D. F. L.; COSTA-NETO, E. M.; FERREIRA, F. Rural populations of Alagoinhas and herpetofauna: knowledge, uses and interactions. Journal of Ethnobiology and Ethnomedicine, London (In press).

CAMURUGI, F.; MAGALHAES, F. D. M.; QUEIROZ, M. H. C.; PEREIRA, T. C. S. O.; TAVARES-BASTOS, L.; LOPESMARINHO, E. D. S.; NEVES, J. M.; GARDA, A. A. Reproduction, sexual dimorphism, and diet of Leptodactylus chaquensis (Anura, Leptodactylidae) in northeastern Brazil. Herpetological Conservation and Biology, Fresno, v. 12, n. 2, p. 498-508, 2017.

DIAS, M. A. S.; LIMA, N. B.; FIGUEIREDO-DE-ANDRADE, C. A. Análise do conhecimento etno-herpetológico dos estudantes no município de Salinas, Minas Gerais, Brasil. Acta Biomedica Brasiliensia, Santo Antônio de Pádua, v. 9, n. 1, p. 36-47, 2018.

FERNANDES-FERREIRA, H.; MENDONÇA, S. V.; CRUZ, R. L.; BORGES-NOJOSA, D. M.; ALVES, R. R. N. Hunting of herpetofauna in montane, coastal, and dryland areas of northeastern Brazil. Herpetological Conservation and Biology, Fresno, v. 8, n. 3, p. 652-666, 2013.

FERREIRA, D. S. S.; CAMPO, C. E. C.; ARAÚJO, A. S. Aspectos da atividade de caça no Assentamento Rural Nova Canaã, município de Porto Grande, estado do Amapá. Biota Amazônia, Amapá, v. 2, n. 1, p. 22-31, 2012.

FERREIRA, F. C. L.; FERREIRA, R. B. Qual a percepção dos moradores do entorno da Reserva Biológica Augusto Ruschi (Espírito Santo, Brasil) sobre os anfíbios anuros? Ethnoscientia, Botucatu, v. 4, p. 1-11, 2019.

IBGE. Pesquisa Nacional por Amostra de Domicílios - PNAD. 2007 Disponível em <https://www.ibge.gov.br/estatisticas/sociais/ educacao/9127-pesquisa-nacional-por-amostra-de-domicilios. html $?=\& \mathrm{t}=\mathrm{O}-\mathrm{que}-\mathrm{e}>$.

IBGE. IBGE cidades. 2017. Disponível em $<$ https://cidades.ibge. gov.br/brasil/ro/porto-velho/panorama>.

LEMOS, L. P.; EL BIZRI, H. R.; VALSECCHI, J.; SANTOS, A. S.; KOGA, D. M; ENNES, F. Caça de vertebrados no Parque Nacional da Serra do Divisor, Acre. Biodiversidade Brasileira, Brasília, v. 8, n. 1, p. 69-88, 2018.

MCCUBBIN, S. G. The Cecil Moment: celebrity environmentalism, Nature 2.0, and the cultural politics of lion trophy hunting. Geoforum, Amsterdam, v. 108, p. 194-203, 2020.

MENDONÇA, L. E. T.; VIEIRA, W. L. S.; ALVES, R. R. N. Caatinga ethnoherpetology: relationships between herpetofauna and people in a semiarid region of northeastern Brazil. Amphibian \& Reptile Conservation, Bournemouth, v. 8, n. 1, p. 24-32, 2014. 
OLIVEIRA, I. S.; FREIRE, E. M. X. Conhecimento ecológico local sobre anfíbios anuros por agricultores em sistemas agrícolas de região semiárida brasileira. Brazilian Journal of Environmental Sciences, Rio de Janeiro, v. 36, p. 198-211, 2015.

OLIVEIRA, M. A; CALOURO, A. M. Hunting agreements as a strategy for the conservation of species: the case of the CazumbáIracema Extractive Reserve, state of Acre, Brazil. Oecologia Australis, Rio de Janeiro, v. 23, n. 2, p. 357-366, 2019.

ONADEKO, A. B.; EGONMWAN, R. I.; SALIU, J. K. Edible amphibian species: local knowledge of their consumption in southwest Nigeria and their nutritional value. West African Journal of Applied Ecology, Legon, v. 19, n. 1, p. 67-76, 2011.

RAMOS, C. G. S.; SANTOS, R. B.; DOS SANTOS, R. W. C.; OLIVEIRA, M. A. Hunting in a community of waste pickers of recyclable materials in Rondônia, Brazil. Revista Brasileira de Ciências da Amazônia, Rolim de Moura, v. 9, n. 3, p. 4-15, 2020.
STAFFORD, C. A.; PREZIOSI, R. F.; SELLERS, W. I. A panneotropical analysis of hunting preferences. Biodiversity and Conservation, New York, v. 26, p. 1877-1897, 2017.

SUPRAYITNO, Q. N.; NARAKUSUMO, R. P.; VON RINTELEN, T.; HENDRICH, L.; BALKE, M. Taxonomy and biogeography without frontiers-WhatsApp, Facebook and smartphone digital photography let citizen scientists in more remote localities step out of the dark. Biodiversity Data Journal, Sofia, v. 5, e19938, p. 1-38, 2017.

VAN VLIET, M. T. H.; FLÖRKE, M.; WADA, Y. Quality matters for water scarcity. Nature Geoscience, London, DOI: 10.1038/ ngeo3047, 2017. 